\title{
Perlambatan migrasi sirkuler: Penilaian terhadap perubahan pola migrasi sirkuler di pedesaan Jawa
}

\author{
The deceleration of circular migration: Assessment of change in \\ the pattern of circular migration in Rural Java
}

\author{
Agung Wicaksono ${ }^{1}$ dan Ardana Kusumawanto ${ }^{2}$ \\ Departemen Antropologi, Fakultas Ilmu Budaya, Universitas Gadjah Mada \\ "Korespondensi penulis: agungwicaksono1987@ugm.ac.id
}

\begin{abstract}
Circular migration has become a well-established institution for rural dwellers in Java. For farmers or unskilled rural workers, informal sectors, construction, or small trade in urban areas provides an adequate working opportunity and, at the same time, a relatively higher wage compared to the agricultural sector. It is frequently argued that migration could reduce poverty in rural areas. Although many harsh critics had been addressed to such arguments, there was relatively little attention given to the dynamics of circular migration itself, as most studies tend to argue that these activities are a constant phenomenon. Based on a comparative survey conducted in Tegal Nduwur Village in 2010 and 2020, this study finds that the rate of circular migration among farmers has significantly decreased. Better market opportunities and deindustrialisation, combined with a shifting development paradigm toward decentralisation since 1999, have gradually improved the village's infrastructure. Under such conditions, the agroecosystem has been transformed from a slow to a fast one. The fast agroecosystem has yielded a more promising outcome for farmers' household economy and absorbed many labor forces, i.e., people who previously migrated to various cities. This condition has decelerated the circular migration flows.
\end{abstract}

Keywords: infrastructure, circular migration, decentralisation, fast agroecosystem, deceleration of migration

\begin{abstract}
ABSTRAK
Migrasi sirkuler telah menjadi institusi yang mapan di daerah pedesaan di Pulau Jawa. Bagi para petani atau penduduk desa yang tidak memiliki keterampilan memadai, sektor informal, konstruksi, dan perdagangan skala kecil di wilayah perkotaan dianggap mampu menyediakan peluang kerja yang melimpah sekaligus tingkat upah yang jauh lebih tinggi. Sering kali dinyatakan bahwa migrasi dapat mengurangi kemiskinan di daerah perdesaan. Meski telah banyak studi yang mengkritik secara tajam dalil tersebut, tetapi gugatan yang diajukan memiliki satu kelemahan mendasar sebab migrasi sirkuler ke daerah perkotaan dianggap sebagai suatu realitas yang konstan. Berbasis pada data survei komparatif pada tahun 2010 dan 2020 di Desa Tegal Nduwur, studi ini menunjukkan bahwa tingkat migrasi sirkuler pada kalangan petani menurun dengan cepat. Peluang pasar yang lebih baik dan deindustrialisasi, yang dikombinasikan dengan pergeseran paradigma pembangunan menuju desentralisasi sejak 1999, secara perlahan menyediakan infrastruktur yang lebih baik. Kondisi ini membantu mengubah agroekosistem, dari yang lambat ke cepat. Kehadiran agroekosistem cepat tidak hanya menghasilkan penghasilan yang lebih baik, tetapi juga menyerap sebagian besar tenaga kerja yang sebelumnya bermigrasi sirkuler. Hal ini memperlambat arus migrasi sirkuler.
\end{abstract}

Kata kunci: infrastruktur, migrasi sirkuler, desentralisasi, agroekosistem cepat, perlambatan migrasi. 


\section{PENDAHULUAN}

\section{Tegal Nduwur, dari Zaman Miskin ke Makmur}

Desa Tegal Nduwur terletak di Kecamatan Bambu Kuning dan berada pada ketinggian 1.522 mdpl. Sebagaimana dataran tinggi dengan ketinggian di atas $1.000 \mathrm{mdpl}$, jagung yang dikombinasikan dengan umbi-umbian menjadi makanan utama penduduk. Dahulu, jagung ditanam dengan sistem non-intensif yang secara lokal dikenal sebagai sistem bedogan. Dalam sistem ini, lahan yang telah dibuka dibersihkan dengan kayul, lembar logam yang diberi tangkai mendatar dan digunakan dengan cara disusupkan ke lapisan tanah atas untuk memotong akar rumput. Permukaan lahan yang sudah bersih dari rumput kemudian ditugal dan diisi bibit jagung serta dibiarkan tumbuh alami (Wicaksono, 2011). Akibatnya, produktivitas pertanian sangatlah rendah sebab setiap hektar lahan hanya menghasilkan sekitar 5 kuintal gabah jagung, yang dipanen sekali dalam setahun. Masa ini mereka kenal sebagai zaman nyara atau sengsara karena hasil panen tidak cukup untuk memenuhi kebutuhan pangan rumah tangga (Wicaksono, 2011).

Pada tahun1980-an, revolusi hijau yang berlangsung agak lambat di dataran tinggi mengubah produktivitas pertanian. Dengan penggunaan bibit unggul, jagung dapat ditanam dua kali dalam setahun. Sementara itu, penggunaan pupuk juga telah meningkatkan produktivitas pertanian hingga nyaris dua kali lipat. Meski mereka sudah tidak lagi kekurangan pangan, kondisi ekonomi rumah tangga belum bisa dikatakan mapan karena terbatasnya penghasilan tunai. Zaman nyara atau sengsara telah berlalu, namun zaman makmur juga belum direngkuh.

Desakan untuk memperoleh uang tunai mendorong sebagian penduduk Tegal Nduwur untuk bekerja di luar daerah. Pada tahun 1980-an, mereka mulai bermigrasi ke wilayah Dieng dan Batur, wilayah dengan kebutuhan tenaga kerja untuk sektor pertanian intensif yang tinggi. Pada dekade berikutnya, generasi yang lebih muda mulai bermigrasi ke wilayah perkotaan dan memasuki sektor informal terutama perdagangan kecil dan konstruksi. Sebagian bermigrasi selama masa jeda antara masa tanam dan panen. Sebagian lagi, terutama pada rumah tangga yang memiliki surplus tenaga kerja, memilih untuk bekerja kontrak dalam waktu yang lebih lama. Dalam jumlah kecil, sebagian perempuan juga bekerja ke kota untuk menjadi asisten rumah tangga. Pada 2010, lebih dari setengah penduduk dewasa Tegal Nduwur telah atau sedang bermigrasi.

Pada Idul Fitri 2010, penulis menyempatkan diri untuk merayakannya di Tegal Nduwur. Penulis menyaksikan bagaimana selepas sholat Ied dan halalbihalal singkat, banyak laki-laki paruh baya langsung berangkat ke Jakarta Utara untuk berjualan Es Cincau. Lebaran adalah kesempatan terbesar untuk meraup penghasilan karena sebagian besar warga Jakarta akan membelanjakan tabungan mereka pada libur panjang. Hingga tahun 2010, migrasi sirkuler ke Jakarta merupakan aktivitas yang lazim, baik untuk berjualan cincau maupun masuk ke berbagai sektor lain seperti konstruksi, perdagangan skala kecil, maupun sektor informal lainnya. Selain Jakarta, mereka juga bermigrasi ke kantong-kantong perkebunan di Jawa, utamanya menjadi buruh tebang tebu ketika musim panen tiba.

Hingga 2010, migrasi sirkuler ke wilayah perkotaan merupakan salah satu jalan utama untuk memperoleh tambahan penghasilan rumah tangga. Migrasi sirkuler tidak hanya menjadi strategi untuk memperoleh uang tunai, tetapi juga untuk mengalirkan surplus tenaga kerja ketika masa jeda pertanian. Migrasi sirkuler ke perkotaan nyaris menjadi aktivitas yang tidak bisa dihindari. "La priwe maning mas, mbarang langka gawean ning umah [mau bagaimana lagi Mas, kenyataannya tersedia sedikit sekali pekerjaan di desa]" kata Kang Musta kepada penulis pada tahun 2010. Ketika melakukan riset di Tegal Nduwur pada Januari 2020, penulis tercengang dengan ucapan Kang Musta, "siki nana wong ngrantau Mas, kabeh balik maning kerja ning ndesa [sekarang tidak ada orang merantau Mas, semua kembali ke desa dan bekerja disini]."

Banyak orang mungkin menyatakan bahwa fenomena yang saat ini berlangsung di Tegal Nduwur ini nampak sebagai anomali, karena umumnya ada anggapan bahwa intensitas migrasi sirkuler dan urbanisasi semakin meningkat. Kasus 
dari Tegal Nduwur menunjukkan kondisi yang bertolak belakang sebab aliran tenaga kerja ke perkotaan justru melambat. Fakta empiris tersebut menuntun studi ini mengajukan satu pertanyaan mendasar yaitu mengapa laju migrasi sirkuler penduduk Tegal Nduwur ke perkotaan menurun drastis? Dengan menyandingkan data mengenai sejarah migrasi pada tingkat desa (mikro) dan perubahan politik ekonomi yang berlangsung di tingkat regional (makro), studi ini berargumen bahwa dalam derajat tertentu, perlambatan migrasi dari wilayah perdesaan ke perkotaan bukanlah sekedar pencilan atau outlier, tetapi menggambarkan perubahan sosial ekonomi yang berlangsung di perdesaan jawa pasca berakhirnya rezim yang sentralistik.

\section{METODE}

Desa Tegal Nduwur yang terletak di Kecamatan Bambu Petung, Kabupaten Pekalongan, merupakan lokus dari studi ini. Desa ini berada pada ketinggian sekitar 1500 mdpl sehingga dapat dikategorikan sebagai wilayah dataran tinggi. Secara metodologis, data etnografis dan data kuantitatif digunakan sebagai dasar untuk membangun tulisan ini. Sebagian besar data etnografis dikumpulkan selama penelitian terdahulu, yang dilakukan pada tahun 2009-2010 selama kurang lebih 12 bulan. Selama periode tersebut, sebagian besar waktu peneliti utama dialokasikan untuk melakukan partisipasi observasi di Desa Tegal Nduwur. Pada periode tersebut, pengumpulan data kuantitatif pada rumah tangga petani juga dilakukan, terutama terkait dengan kepemilikan tanah, ternak, riwayat migrasi, jenis tanaman, dan jumlah anggota rumah tangga.

Pada bulan Januari dan Februari tahun 2020, peneliti utama yang kali ini dibantu asisten peneliti melakukan penelitian survei di 4 desa di Kecamatan Bambu Kuning, termasuk Desa Tegal Nduwur. Secara total, ada 400 responden yang diwawancarai. Enumerator adalah mahasiswa sarjana yang berjumlah 10 orang. Di tiap desa, 100 responden dipilih secara purposive random sampling. Responden diutamakan berasal dari dusun induk dan, jika belum memenuhi jumlah yang dibutuhkan, responden diambil dari dusundusun berikutnya. Pada tulisan ini, hanya data dari Desa Tegal Nduwur yang dianalisis. Data kualitatif dan kuantitatif ditelaah secara hati-hati untuk melihat perubahan pola migrasi pada 2010 dan 2020 .

\section{HASIL DAN PEMBAHASAN}

\section{Migrasi Sirkuler dan Pasang Surut Pembangunan Perdesaan}

Pada tahun 1950-an, penduduk yang menetap di perkotaan Asia Tenggara berkisar pada angka 14\%. Pada tahun 1975 dan 2000, jumlah tersebut meningkat menjadi 22\% dan 37\%, dan diproyeksikan mencapai 53\% pada 2025 (Jones, 2002). Proses yang lazim disebut sebagai urbanisasi ini terkait erat dengan gagasan ekonom neoklasik mengenai tumbuhnya ekonomi modern yang berlangsung seiring dengan transisi dari pertanian ke industri (Lewis, 1954). Namun, proses pertumbuhan sektor industri tidaklah berlangsung secara merata di semua negara, contohnya di Indonesia. Sebagaimana diungkapkan oleh Gordon (1982), mode produksi kolonial mungkin telah menghambat tumbuhnya sektor industri berbasis manufaktur. Perkiraan Gordon tersebut bukanlah isapan jempol semata karena data empiris yang disajikan oleh White (1991) menunjukkan bahwa hingga menjelang kemerdekaan, sebagian besar sektor ini diisi oleh industri skala kecil dan rumahan.

Pasca-kemerdekaan, turbulensi politik ekonomi yang datang bertubi-tubi pada dekade 1950an dan 1960-an (Booth, 2016) menghadirkan halangan besar bagi tumbuhnya sektor industri yang mapan. Pada dekade 1960-an, pergerakan tenaga kerja yang lazim berlangsung bukanlah dari desa ke kota, tetapi antarwilayah (McNicoll, 1968). Kondisi yang membuat Indonesia dilabeli dengan ekonomi suram ini mulai luntur seiring dengan kemampuan pemerintah menekan inflasi, penyediaan kebijakan pro-investasi, dan ledakan harga minyak (Booth, 2016). Hasilnya adalah pertumbuhan output industri yang pesat dari $13,3 \%$ pada 1971 menjadi $33,8 \%$ pada 1995 (Booth, 2016, 66-67). Tingginya tingkat ekonomi terutama di wilayah urban tidak hanya memicu urbanisasi, tetapi juga migrasi sirkuler.

Migrasi sirkuler didefinisikan sebagai pergerakan sistematis dan reguler dari migran antara 
negara asal dan luar negeri, terutama untuk bekerja (Constant \& Zimmerman, 2011). Secara lebih jeli, Hugo (2009) menyatakan bahwa migrasi sirkuler juga dapat berlangsung dalam batas geografis suatu negara. Ia mendefinisikan migrasi sirkuler tipe ini sebagai merantau, atau tinggal dalam jangka waktu tertentu di luar wilayah untuk bekerja (Hugo, 1977). Dalam aktivitas ini, masing-masing aktor memiliki latar belakang dan tujuan yang berbeda. Bagi para tuna kisma, migrasi sirkuler ditujukan untuk menyambung hidup ketika pekerjaan pertanian sangat terbatas setelah masa tanam dan sebelum panen berlangsung. Pada desa-desa dengan surplus tenaga kerja yang tinggi, mereka bahkan bermigrasi sirkuler secara lebih lama (Hugo, 1977). Sebagian petani pemilik tanah juga melakukan migrasi sirkuler dengan tujuan untuk mengalirkan tenaga kerja produktif ke luar sektor pertanian (Hetler, 1989).

Selain latar belakang ekonomi, politik, umur, gender dan aspirasi dari para migran, berbagai studi mengenai migrasi sirkuler seringkali menitikberatkan pada aspek positif atau negatif aktivitas ini. Sebagian membahas efek positif dan negatif secara bersamaan (Hugo, 2009), sementara sebagian lagi membahasnya secara terpisah. Mereka yang menitikberatkan pada sisi positif dan optimistik menyatakan bahwa migrasi sirkuler mampu mengurangi kemiskinan dan berkontribusi positif terhadap ekonomi rumah tangga (Hugo, 1977; Hetler 1989), mendorong kosmopolitanisme perdesaan (Gidwani \& Sivaramakrishnan, 2003), dan dalam kasus antarnegara, menghindari brain drain serta menghasilkan winwin wsituation, suatu kondisi yang memberikan manfaat bagi negara pengirim, negara penerima, dan migran itu sendiri (Vertovec, 2007; Zimmermann, 2014). Meski tidak mutlak, ini juga berkontribusi terhadap pembangunan (Skeldon, 2013). Di sisi lain, mereka yang melihat migrasi sirkuler secara kritis menyatakan bahwa aktivitas ini justru menghasilkan kerugian ganda bagi para pelakunya (Moniruzzaman \& Walton-Roberts, 2018), posisi yang senantiasa ambivalen dan insecure (Triandafyllidou, 2013), atau bahkan memperburuk kondisi di wilayah asal (Makhrova dkk., 2016). Meski demikian, ada pula studi yang melihat migrasi sirkuler dalam perspektif yang lebih realistis (Wickramasekara, 2011).
Beragam studi tersebut memberikan pemahaman komprehensif atas berbagai isu yang melekat pada migrasi sirkuler. Namun, keduanya terjebak pada lubang yang sama karena cenderung melihat migrasi sirkuler sebagai peristiwa sosial yang berlangsung konstan. Kalaupun ada pasang surut, hal ini ditempatkan sebagai outlier atau pencilan semata berdasarkan asumsi bahwa dalam konteks domestik, wilayah perkotaan senantiasa menyediakan peluang kerja yang lebih baik, baik secara kualitas maupun kuantitas, sehingga tenaga kerja dari perdesaan terus mengalir ke wilayah ini. Ada dua kelemahan mendasar dari gagasan yang demikian. Pertama, kondisi politik ekonomi suatu negara senantiasa mengalami oskilasi bahkan kadangkala mencapai krisis. Ketika krisis menyapu, baik urbanisasi maupun migrasi sirkuler tidak hanya mengalami kontraksi, tetapi bahkan mengalir melalui arah yang berlawanan, dari perkotaan ke perdesaan (Mizuno, 2016). Dalam konteks terkini, pandemi Covid-19 telah menghasilkan kondisi serupa (Srivastava, 2020). Kembali ke kasus Indonesia, krisis ekonomi yang berlangsung pada 1998 adalah contoh yang tepat (Mizuno, 2016). Kedua, gagasan yang demikian juga cenderung pro status quo karena menganggap bahwa daerah pinggiran senantiasa miskin dan kurang sumber daya. Alih-alih melihatnya sebagai sesuatu yang tercipta secara alamiah, kemiskinan perdesaan juga harus dilihat dalam kaitannya dengan struktur politik ekonomi yang sentralistik, khususnya selama Orde Baru (19661998). Dalam pandangan Syaukani dkk. (2016), sistem sentralistik cenderung mengutamakan pusat sehingga wilayah pinggiran yang hanya menerima sedikit manfaat (Semedi, 2006).

Runtuhnya Orde Baru diikuti oleh dua hal yang membantu merekonfigurasi migrasi sirkuler. Pertama, proses deindustrialisasi. Kondisi ini membuat wilayah perkotaan tidak menyediakan lapangan kerja dalam jumlah besar karena pada derajat tertentu, penggerak roda ekonomi nasional justru wilayah pinggiran melalui budi daya tanaman komoditas (Mizuno, 2016). Kedua, transisi kebijakan desentralistik yang berlangsung secara bertahap, dimulai dari otonomi daerah (Syaukani dkk., 2016) hingga otonomi desa (Antlöv dkk., 2016). Dikeluarkannya UU Desa No. 6 Tahun 2014 memungkinkan desa untuk memperoleh 
dana kerja kurang lebih satu milyar per tahun. Dengan ketersediaan sumber dana rutin dalam jumlah cukup besar setiap tahunnya, pembiayaan berbagai proyek, baik infrastruktur, kelembagaan, maupun pemberdayaan menjadi semakin fisibel untuk dijalankan.

Di Tegal Nduwur, sebagian dana desa dialokasikan untuk membangun jalan tani. Meski nampak sederhana, pembangunan infrastruktur pertanian ini mampu merangsang perubahan agroekosistem secara cepat. Santoso (2015) mengelompokkan karakter agroekosistem ke dalam tiga kategori, yaitu (i) agroekosistem lambat; (ii) agroekosistem sedang; dan (iii) agroekosistem cepat. Agroekosistem lambat dicirikan oleh kondisi ekologis rentan, tidak dikelola secara intensif, dan umumnya hanya ditujukan untuk memenuhi kebutuhan subsisten. Pertanian lahan kering dan ladang mewakili tipe ini. Agroekosistem sedang dicirikan oleh kondisi ekologis yang stabil, dikelola dengan cukup intensif, dan berproduksi untuk memenuhi kebutuhan subsisten sekaligus pasar. Sawah mewakili tipe ini. Kategori ketiga adalah agroekosistem cepat, yang dicirikan oleh kondisi ekologis rentan, namun dikelola dengan sangat intensif dan spekulatif, sementara produknya ditujukan untuk kebutuhan pasar baik domestik maupun ekspor (Santoso, 2015).

Artikel ini berargumen bahwa insentif pasar yang semakin besar dengan naiknya harga komoditas sayuran, dikombinasikan dengan kebijakan desentralisasi yang memudahkan pembangunan infrastruktur perdesaan seperti jalan tani telah berperan besar dalam mengubah sebagian agroekosistem di wilayah perdesaan. Di dataran tinggi, transformasi ini berlangsung dari agroekosistem lambat ke agroekosistem cepat. Dibangunnya jalan tani memangkas biaya produksi baik untuk penanaman, perawatan maupun pemanenan sehingga menyediakan insentif besar bagi petani untuk mengubah agroekosistem mereka. Orientasi pasar terutama domestik yang menguntungkan, dikombinasikan dengan budidaya intensif nan spekulatif menyediakan peluang besar bagi penduduk desa untuk meningkatkan penghasilan pertanian, menyerap tenaga kerja dalam jumlah besar, dan memberikan tingkat upah yang lebih baik.
Meluasnya agroekosistem cepat dengan budidaya intensif nan spekulatif tidak hanya berlangsung di Tegal Nduwur, namun juga menyapu sebagian besar wilayah frontier Indonesia melalui kelapa sawit dan berbagai tanaman komoditas lain (Hidayat dkk., 2018; Petrenko dkk., 2016; Semedi, 2014; Li, 2014). Selain magnitude dan jenis komoditas yang ditanam, apa yang membedakan Tegal Nduwur dengan wilayah frontier tersebut adalah peran negara dan sumber tenaga kerja. Di wilayah frontier, peran negara dalam menggerakkan transformasi tidaklah begitu signifikan sementara budidaya dilakukan dengan memanfaatkan tenaga kerja yang dioperasikan untuk menjalankan budidaya didatangkan dari supra desa, terutama transmigran. Di Tegal Nduwur, meski insentif pasar cukup besar, namun peran negara juga tidak kalah besar. Sementara dari sisi tenaga kerja, budidaya intensif yang menghasilkan agroekosistem cepat dipenuhi dari tenaga kerja domestik (Santoso, 2015). Penggunaan tenaga kerja domestik untuk mendukung agroekosistem cepat inilah yang mengerem laju migrasi sirkuler. Apalagi saat ini, wilayah perdesaan memungkinkan generasi muda untuk seek out and enact a rural modern lifestyle menemukan dan menjalankan gaya hidup modern perdesaan (White, 2020, 116).

\section{Lanskap Pertanian dan Migrasi Sirkuler Petani Tegal Nduwur pada 2010}

Hingga tahun 2010, pertanian padat modal dan tenaga kerja hanya dilakukan dalam skala terbatas. Keterbatasan modal, jejaring, informasi, dan infrastruktur membuat hanya sedikit petani yang mau dan mampu berspekulasi. Sebagian besar penduduk Tegal Nduwur, seperti halnya desadesa di lereng utara Pegunungan Serayu yang membentang dari Kabupaten Temanggung hingga Tegal, cenderung melakukan diversifikasi tanaman yaitu tanaman subsisten, semi komersial, dan tanaman pendukung seperti kayu-kayuan untuk memasak, atau rerumputan untuk pakan ternak. Gambar 1 menyajikan data mengenai penggunaan lahan di Tegal Nduwur pada tahun 2010.

Pada 2010, budi daya tanaman subsisten sangat dominan karena 347 petak lahan (50\%) ditanami jagung. Meski beras sudah mulai lazim 


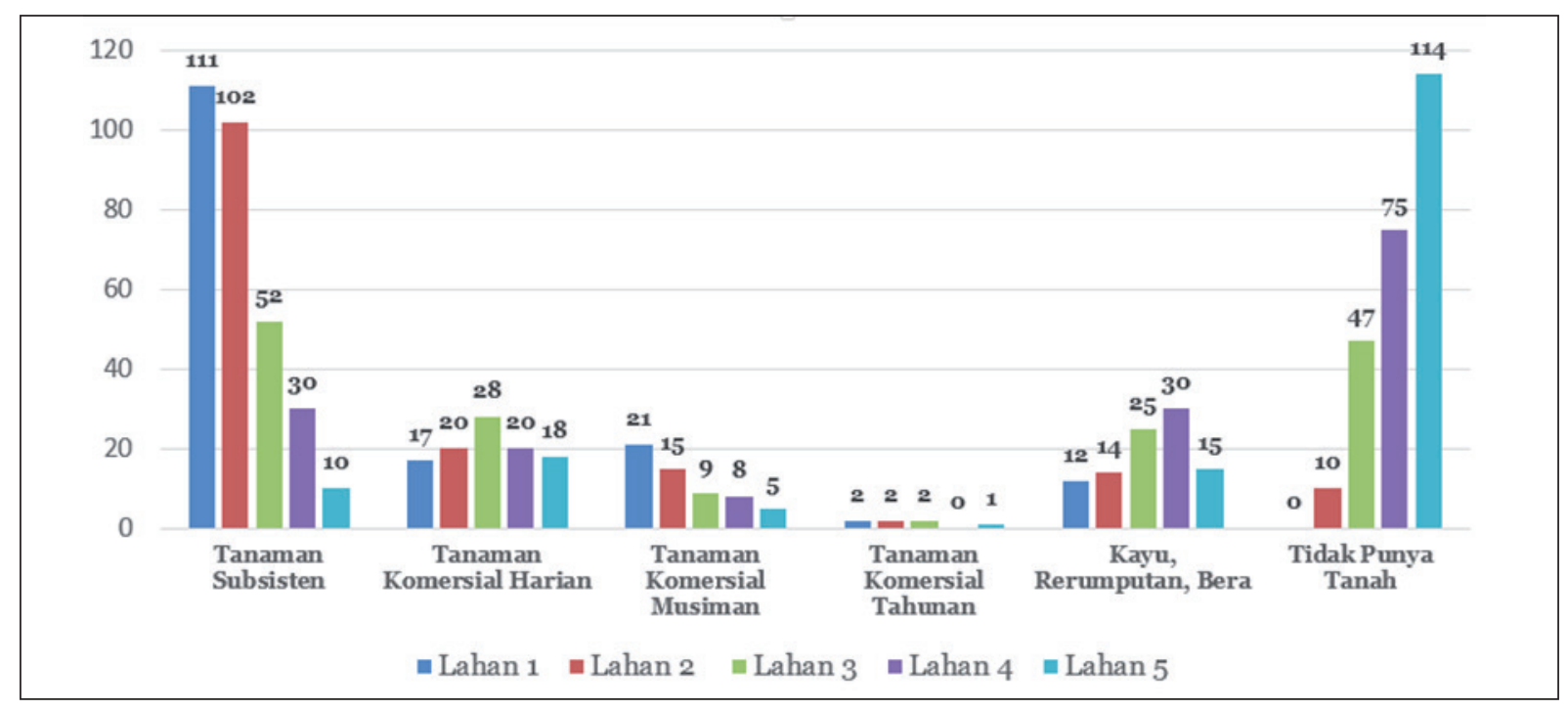

Sumber: Data penelitian lapangan (2009-2010)

Gambar 1. Jenis Tanaman Utama pada Tiap Petak Lahan

dikonsumsi oleh masyarakat lapis ekonomi atas, jagung merupakan makanan pokok bagi sebagian besar warga. Secara agregat, budidaya tanaman komersial juga cukup signifikan (33\%). Tanaman komersial atau yang sepenuhnya ditujukan untuk pasar dapat diklasifikasikan menjadi tiga kelompok berdasarkan masa panen yaitu harian, musiman dan tahunan. Tanaman komersial harian secara umum berbiaya produksi agak rendah dan memberikan penghasilan yang lumayan bagi petani. Teh dan daun bawang termasuk dalam kelompok ini dan persentasenya cukup dominan yaitu $19 \%$. Tanaman komersial musiman adalah tanaman (terutama sayuran) yang dibudidayakan selama satu musim tanam seperti kentang, wortel, cabai, dan kubis. Tanaman komersial musiman, terutama kentang, memerlukan biaya produksi yang sangat tinggi. Pada 2010, sebanyak 12\% petak lahan ditanami kentang. Untuk tipe ketiga, yaitu tanaman komersial tahunan seperti tembakau, budidayanya terus menerus mengalami penurunan sehingga dapat dikesampingkan.

Secara agregat, Gambar 1 juga menunjukkan bahwa proporsi lahan yang ditanami pepohonan dan rerumputan yang digunakan untuk kayu bakar dan pakan ternak cukup besar, yaitu sekitar 17\%. Pola tanam agregatif kurang lebih merepresentasikan pola tanam rumah tangga Ketika para petani mengombinasikan budidaya tanaman subsisten dengan tanaman komersial. Diversifikasi tanaman dapat ditafsirkan sebagai upaya petani untuk mem- pertahankan subsistensi rumah tangga. Namun, tafsir yang demikian cenderung menempatkan petani sebagai aktor-aktor yang pasif dan kurang peka terhadap peluang pasar. Sebagaimana dapat dicermati dari kasus Tegal Nduwur, keengganan untuk mengadopsi budidaya tanaman komersial berlangsung karena kehati-hatian mereka untuk melakukan investasi.

Selain dari sektor pertanian, subsistensi rumah tangga dipenuhi dengan mencadangkan sebagian lahan untuk tanaman kayu sementara tambahan penghasilan tunai diperoleh dari ternak. Secara historis, pemeliharaan ternak terintegrasi dengan pertanian terutama untuk mendukung penyediaan pupuk dan mekanisme tabungan. Pada awalnya, meski tidak saklek, petani yang cukup makmur memilih untuk memelihara sapi karena kondisi ekonomi sehari-hari yang relatif stabil. Sementara itu, para petani kecil cenderung memilih kambing agar mudah diperjualbelikan ketika ekonomi rumah tangga mengalami pasang surut. Pola ini sedikit mencair ketika sistem nggaduh muncul sehingga para petani kecil dapat memelihara sapi dengan modal dari petani kaya. Pemeliharaan sapi di kalangan petani Bambu Kuning meluas pada awal 1980-an seiring dengan tingginya kebutuhan daging di pasar domestik (Nusrat, 2003). Gambar 2 menyajikan distribusi pemeliharaan kambing di Desa Tegal Nduwur.

Pemeliharaan kambing pada petani Tegal Nduwur cukup merata sebab $78 \%$ rumah tangga 


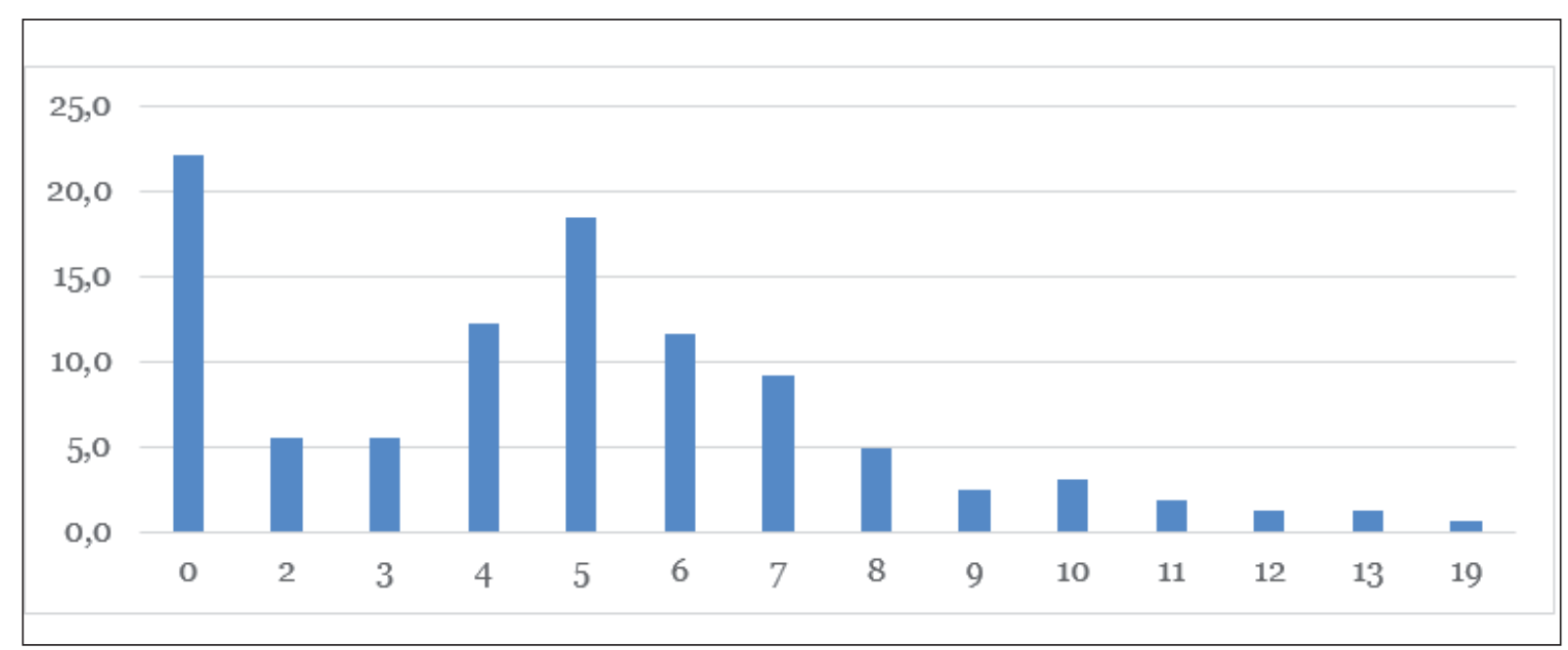

Sumber: Data penelitian lapangan (2010)

Gambar 2. Kepemilikan Kambing Petani Tegal Nduwur

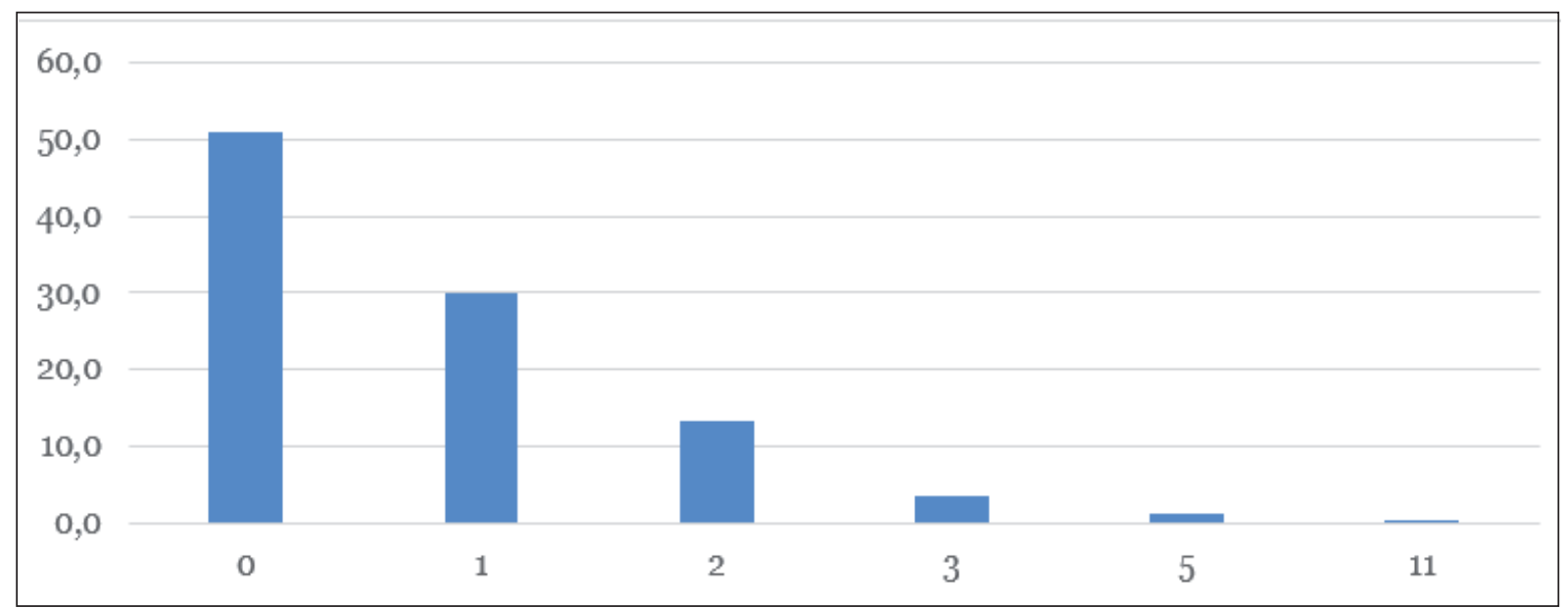

Sumber: Data penelitian lapangan (2010)

Gambar 3. Kepemilikan Sapi Petani Tegal Nduwur

memeliharanya. Tingginya angka pemeliharaan kambing memiliki berbagai alasan yaitu harga yang tidak terlalu mahal, cepat beranak (satu tahun satu kali), dan mudah diperjualbelikan. Sebagian besar petani memelihara antara 4-8 kambing per rumah. Hal ini terkait erat dengan kebutuhan tenaga kerja. Setiap ekor kambing dewasa memerlukan sekitar $10 \mathrm{~kg}$ rumput perhari sehingga secara agregat, satu unit rumah tangga harus menyediakan 40-80 kg rumput. Setiap merumput, laki-laki dewasa menghabiskan waktu sekitar 2 jam untuk menghasilkan $50 \mathrm{~kg}$ rumput (satu pikul) sehingga jika memelihara lebih dari 8 ekor kambing, setiap rumah tangga perlu mengalokasikan 6 jam kerja tenaga laki-laki dewasa per hari untuk penyediaan rumput. Pada titik ini, ketersediaan tenaga kerja rumah tangga menjadi variabel penting dalam me- nentukan berapa jumlah kambing yang dapat dipelihara oleh sebuah rumah tangga.

Di Tegal Nduwur, pemeliharan sapi juga cukup tinggi (50\%). Secara ekonomi, harga sapi jauh lebih mahal dibanding kambing. Dengan semakin mudahnya sistem maro (nggaduh), lebih rendahnya pemilikan sapi dipengaruhi oleh faktor non-ekonomi. Ada dua faktor yang berpengaruh terhadap pemeliharaan sapi yaitu adalah tenaga kerja dan lahan untuk merumput. Setiap ekor sapi dewasa memerlukan sekitar $40 \mathrm{~kg}$ rumput per hari. Sementara itu, sebagian besar rumah tangga petani telah memelihara kambing. Oleh karena itu, pemeliharaan sapi memaksa mereka untuk mengoptimalkan penggunaan tenaga kerja. Pada 2010, rata-rata anggota keluarga rumah tangga petani di Tegal Nduwur adalah 4,36. Jika diperkirakan bahwa 
sepertiganya non produktif - karena terlalu muda atau terlalu tua - maka tenaga kerja yang tersedia untuk segala jenis urusan, mulai dari rumah tangga, pertanian hingga ternak hanya tiga orang saja. Faktor lain yang berpengaruh adalah ketersediaan lahan merumput. Jenis rumput yang dikonsumsi dan lahan sumber rumput relatif sama. Oleh karena itu, terjadi kompetisi di antara pemeliharaan kedua jenis ternak ini sehingga pemeliharaan kambing berkorelasi negatif terhadap pemeliharaan sapi. Artinya, semakin banyak jumlah kambing, semakin sedikit jumlah sapi yang dipelihara dan sebaliknya. Selain untuk pemeliharaan ternak, para petani mengalirkan sebagian tenaga mereka untuk melakukan migrasi sirkuler dalam upaya menambah penghasilan. Hal ini dapat dicermati pada Gambar 4.

Pada 2010, sekitar 56\% penduduk Tegal Nduwur yang berusia minimal 17 tahun pernah dan masih melakukan migrasi sirkuler. Sebagaimana pola umum di pedesaan Jawa, Gambar 4 menunjukkan bahwa sebagian besar bekerja di Jakarta. Sejak awal 1990-an, tenaga kerja laki-laki mengalir secara temporer di sektor konstruksi dan perdagangan skala kecil. Sebagian lain memilih bekerja secara temporer di Pekalongan yang relatif lebih dekat sementara aliran tenaga kerja di luar kedua tempat tersebut sangatlah minor. Dalam menjalankan migrasi sirkuler, ada perbedaan aspirasi dan keleluasaan yang signifikan antara penduduk yang sudah menikah dan belum menikah, atau lajang. Bagi mereka yang sudah menikah, migrasi sirkuler benar-benar ditempatkan sebagai salah satu tumpuan ekonomi rumah tangga. Bagi kelompok ini, kapan waktu bermigrasi sangat ditentukan oleh kondisi rumah tangga sebagaimana muncul dari percakapan penelitian tahun 2009:
Peneliti: Kemarin katanya mau berangkat ke Jakarta (untuk berjualan es cincau) Pak?

Pak Rusli: Dereng ngertos Mas, dereng kober, sakniki nembe med pasir, med kayu, ajeng manja Lombok (Belum tahu Mas, masih sangat sibuk, sekarang sedang mengumpulkan pasir, mencari kayu, dan masih harus menanam cabai). (Catatan penelitian 5 Maret 2009)

Percakapan tersebut mengindikasikan bahwa sebelum berangkat bermigrasi, baik ke Jakarta atau ke kota lain, mereka ingin memastikan bahwa kebutuhan dasar di rumah seperti kayu bakar telah disediakan dan pekerjaan-pekerjaan pertanian yang berat telah diselesaikan. Para perempuan cenderung tinggal di desa, untuk mengurus beragam persoalan domestik, kerja pertanian, dan dalam batas tertentu, memelihara ternak. Terbatasnya sumber uang tunai di desa juga mendorong generasi muda Tegal Nduwur berangkat ke Jakarta. Pada 2010, Fatah yang berumur 13 tahun sudah bekerja bersama temanteman sebayanya di sebuah kantin perusahaan. Tidak hanya di Jakarta, sebagian pemuda bahkan memiliki pengalaman migrasi yang lebih luas.

Pada awalnya, Anto mulai bekerja sebagai kuli bangunan di Jakarta dan Bogor. Ia juga pernah bekerja sebagai buruh pemanen tebu di Lampung. Anto juga pernah bekerja di Kabupaten Pati sebagai buruh ukir kayu (Catatan penelitian 4 Maret 2009).

Kasus Anto di atas menunjukkan bagaimana upaya generasi muda Tegal Nduwur untuk mencoba bekerja di berbagai sektor. Harapan utamanya, mereka memiliki tabungan yang dapat digunakan untuk membeli motor, modal perayaan pernikahan, memperbaiki rumah, atau membantu kehidupan

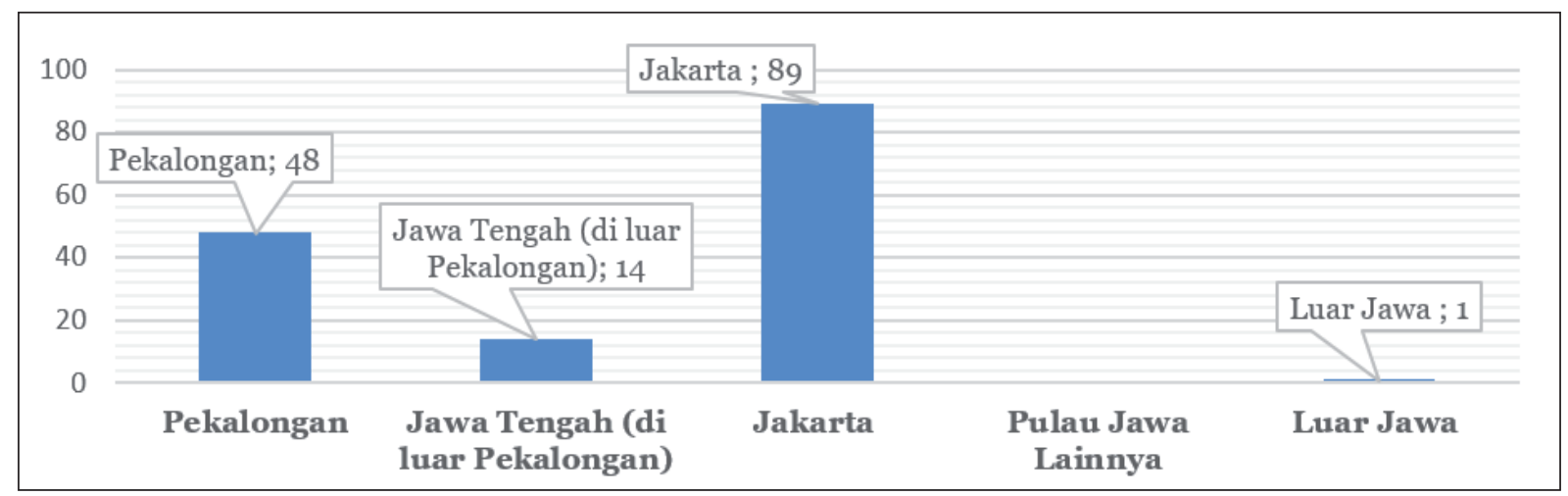

Sumber: Data penelitian lapangan, 2010

Gambar 4. Riwayat Migrasi Penduduk Tegal Nduwur 
orang tua. Meski demikian, gagasan yang begitu baik tersebut tidak selalu dapat direalisasikan dengan mudah. Dalam beberapa kasus, mereka mengatakan bahwa kalau kerja di luar, "uang banyak atau sedikit sama saja, sama-sama pulang dengan tangan kosong". Hal ini karena sering kali, uang hasil kerja digunakan untuk berfoya-foya, main ke tempat hiburan dan rekreasi, membeli pulsa dan rokok secara berlebihan, atau sekedar kencan dengan teman wanita mereka. Ketika Marto ditanyai oleh bibinya mengenai uang hasil kerja di Jakarta, ia menjawab dengan sekenanya "duit apa, inyong kerjo ra entuk apa-apa [uang apa, saya bekerja, namun tidak mendapatkan banyak uang]" karena memang tabungannya hanya tersisa sedikit setelah dibelanjakan di sana.

Realitas di atas menunjukkan bahwa orientasi utama bermigrasi bagi setiap aktor berbeda. Bagi yang telah menikah, tambahan penghasilan untuk menopang rumah tangga adalah tujuan utama. Sementara bagi yang belum menikah, migrasi sirkuler tidak hanya terkait uang dan tabungan, tetapi juga pemenuhan aspirasi mereka sebagai anak muda. Jika dilihat dengan kacamata non-kritis, kita menyaksikan suatu citra ideal rumah tangga petani yang memiliki kemampuan mengombinasikan beragam aktivitas ekonomi. Pertanian untuk pemenuhan subsistensi, ternak untuk tabungan atau kebutuhan mendesak, sementara uang hasil migrasi digunakan untuk memenuhi kebutuhan seharihari. Namun, karena basis utama ketiga variabel ini adalah tenaga kerja, perubahan konfigurasi pada satu variabel dengan segera memengaruhi variabel-variabel lainnya. Tingginya migrasi dan pemeliharaan ternak di kalangan petani Tegal Nduwur harus ditempatkan sebagai variabel terpengaruh atas pola pertanian yang bercorak subsisten. Pertanian subsisten yang tidak memerlukan pengelolaan intensif memungkinkan atau bahkan memaksa mereka untuk mengoptimumkan tenaga kerja yang tersedia untuk memelihara ternak dan migrasi. Implikasinya, sebagaimana akan kita lihat pada bagian berikutnya, ketika terjadi perubahan mode pertanian dari subsisten ke komersial yang padat modal dan tenaga kerja, pemeliharaan ternak dan migrasi sirkuler memperoleh dampak yang begitu besar.

\section{Pembangunan Infrastruktur dan Adopsi Agroekosistem Cepat}

Pada tahun 1985, Kecamatan Bambu Kuning ditetapkan sebagai wilayah paling terisolisasi kedua di Provinsi Jawa Tengah, setelah Karimunjawa. Persoalan utama keterisolasian ini bukanlah semata geografis, tetapi ketiadaan infrastruktur yang memadai. Jalan yang dibangun antar desa hanya bertahan selama satu hingga tiga tahun sebelum akhirnya berubah kembali menjadi makadam. Sementara akses penduduk untuk menuju areal pertanian hanya memanfaatkan jalan tanah selebar setengah hingga satu meter. Buruknya infrastruktur jalan bukan semata karena ketiadaan program pembangunan, tetapi kebijakan top-down yang membuatnya menjadi kue rayahan (Semedi, 2006). Orientasi pembangunan bottom-up yang diinisiasi sejak tahun 1999 mulai memunculkan hasil dalam satu dekade terakhir. Jenis dan skala program-program pembangunan yang diusulkan dari tingkat bawah tidak hanya memungkinkan sistem pengawasan yang lebih transparan, tetapi juga mengurangi potensi salah sasaran. Pada tahun 2011, memanfaatkan program PNPM, dibuat jalan usaha tani selebar 1,2 meter yang menghubungkan antara jalan utama dengan wilayah pertanian di sisi utara desa sepanjang satu kilometer. Pada periode 2016-2018, jalan serupa dibuat di sisi selatan desa yang panjangnya hampir mencapai satu kilometer. Bagi orang luar, jalan usaha tani selebar 1,2 meter mungkin dilihat sebagai sesuatu yang tidak terlalu bermanfaat. Namun di Tegal Nduwur yang berlokasi di pegunungan, infrastruktur ini membuat aksesibilitas ke wilayah pertanian sehingga mampu mengubah agroekosistemnya. Jalan tani yang dibangun sejak tahun 2011 mampu menekan biaya produksi. Sebelum adanya jalan tani, pengangkutan bibit, pupuk, dan hasil panen hanya dapat dilakukan dengan cara dipikul. Adanya jalan tani membuat berbagai aktivitas tersebut dapat diselesaikan dengan menggunakan sepeda motor sehingga jauh lebih cepat dan murah.

Gambar 5 menggambarkan bagaimana agroekosistem cepat berlangsung di Tegal Nduwur. Pertama, dari 100 responden, tidak ada satupun yang telah menjadi tuna kisma meski jumlah rumah tangga yang memiliki banyak petak tanah semakin sedikit. Dari jenis tanaman yang dibudi- 
dayakan, terjadi perubahan signifikan karena pada musim tanam 2019, hanya satu responden yang menanam jagung, itupun di petak kelima. Perubahan pola budidaya tanaman subsisten juga diterangkan oleh perubahan konsumsi. Ketika penulis menjalankan riset pada bulan Januari 2020, mereka mengatakan bahwa saat ini, pangan utama mereka adalah beras. Namun, karena beras tidak diproduksi disini, sebagian besar warga Tegal Nduwur harus membelinya di pasar dan ini hanya dapat berlangsung jika mereka memiliki uang tunai secara lebih stabil.

Gambar 5 menunjukkan bahwa budidaya tanaman komersial harian dan tahunan hanya mengalami sedikit perubahan. Meski jenis dan pola budidayanya berbeda, keduanya dapat diklasifikasikan ke dalam agroekosistem sedang. Hal ini dikarenaka keduanya dianggap stabil, serta kebutuhan modal dan tenaga kerjanya relatif tidak terlalu besar. Perubahan signifikan berlangsung pada budidaya tanaman komersial musiman seperti kentang, cabai, dan wortel. Berbagai tanaman ini, terutama cabai dan kentang, dapat diklasifikasikan ke dalam tanaman agroekosistem cepat karena memerlukan modal yang tinggi, curahan tenaga kerja yang intensif, serta risiko kegagalan yang sangat tinggi. Transisi ke arah agroekosistem cepat memaksa petani melakukan beberapa penyesuaian. Besarnya ongkos yang harus dikeluarkan untuk biaya produksi mendorong sebagian rumah tangga petani berhutang. Implikasinya, sistem hutang untuk budidaya tanaman menjadi semakin intensif, apalagi jika dibandingkan dengan desa-desa di sekitarnya.

Upaya untuk menekan biaya produksi juga dilakukan dengan pemusatan tenaga kerja rumah tangga. Jika tenaga kerja rumah tangga dianggap konstan, maka skema zero sum game berlangsung. Disini, skema zero sum game berlangsung ketika meningkatnya kebutuhan tenaga kerja untuk budidaya tanaman komersial dipenuhi dengan mengurangi aliran tenaga kerja ke sektor pemeliharaan ternak dan migrasi. Gambar 6 menunjukkan bagaimana kondisi zero sum game yang berlangsung pada pemeliharaan ternak.

Data survei terhadap 100 rumah tangga petani di Desa Tegal Nduwur menunjukkan hasil yang begitu mengejutkan karena tidak satupun responden memelihara sapi, baik milik sendiri atau dengan sistem gaduhan. Padahal pada 2010, 50\% rumah tangga petani di desa ini memelihara sapi. Jika melihat Gambar 6, merosotnya pemeliharaan sapi di kalangan petani Tegal Nduwur sepertinya bukan implikasi atas berkurangnya areal merumput karena lahan untuk rumput tidaklah mengalami perubahan signifikan. Selain itu, mereka masih bisa mengandalkan rumput di areal Perhutani. Oleh karena itu, merosotnya pemeliharaan sapi lebih tepat ditafsirkan sebagai implikasi atas ketidakmampuan mereka menyediakan tenaga kerja rumah tangga untuk penyediaan rumput.

Pemeliharan kambing juga menghadapi kemerosotan yang tidak kalah signifikan. Pada 2010,

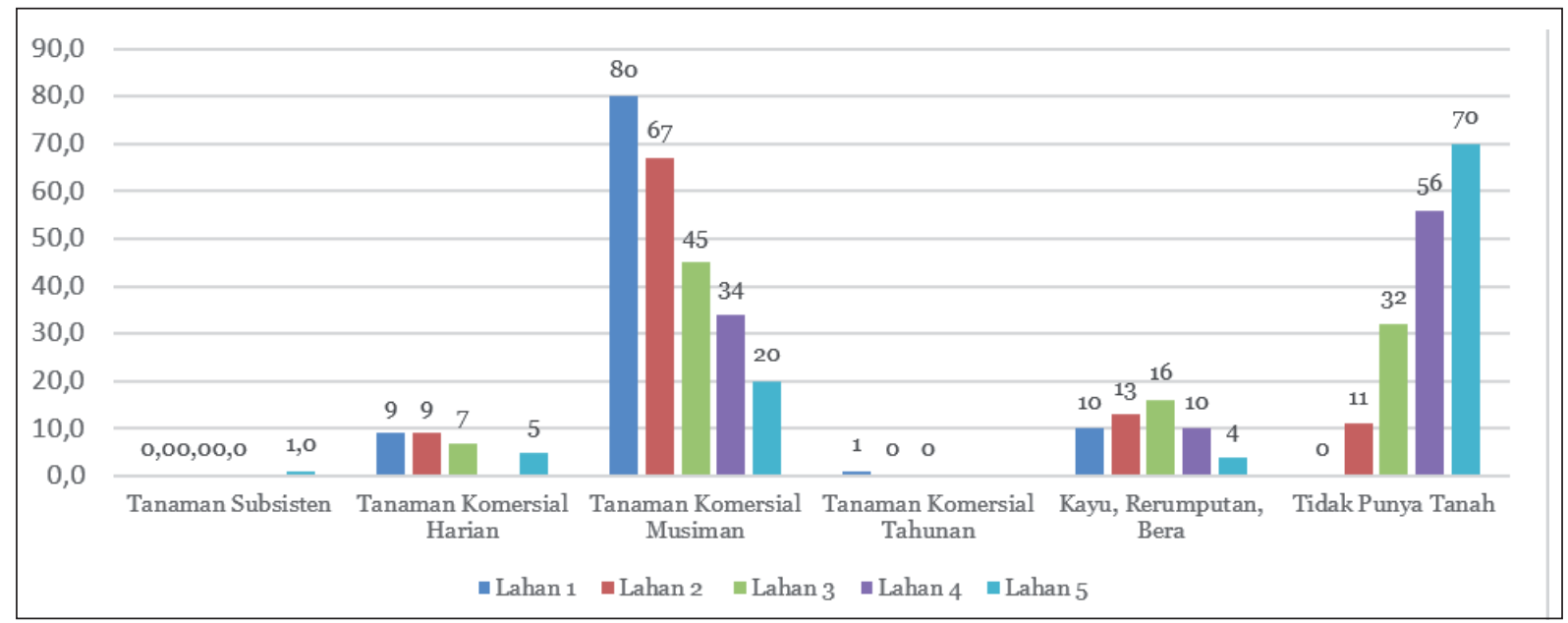

Sumber: Data survei rumah tangga, $2020(\mathrm{n}=100)$

Gambar 5. Jenis Tanaman pada Lahan Petani 


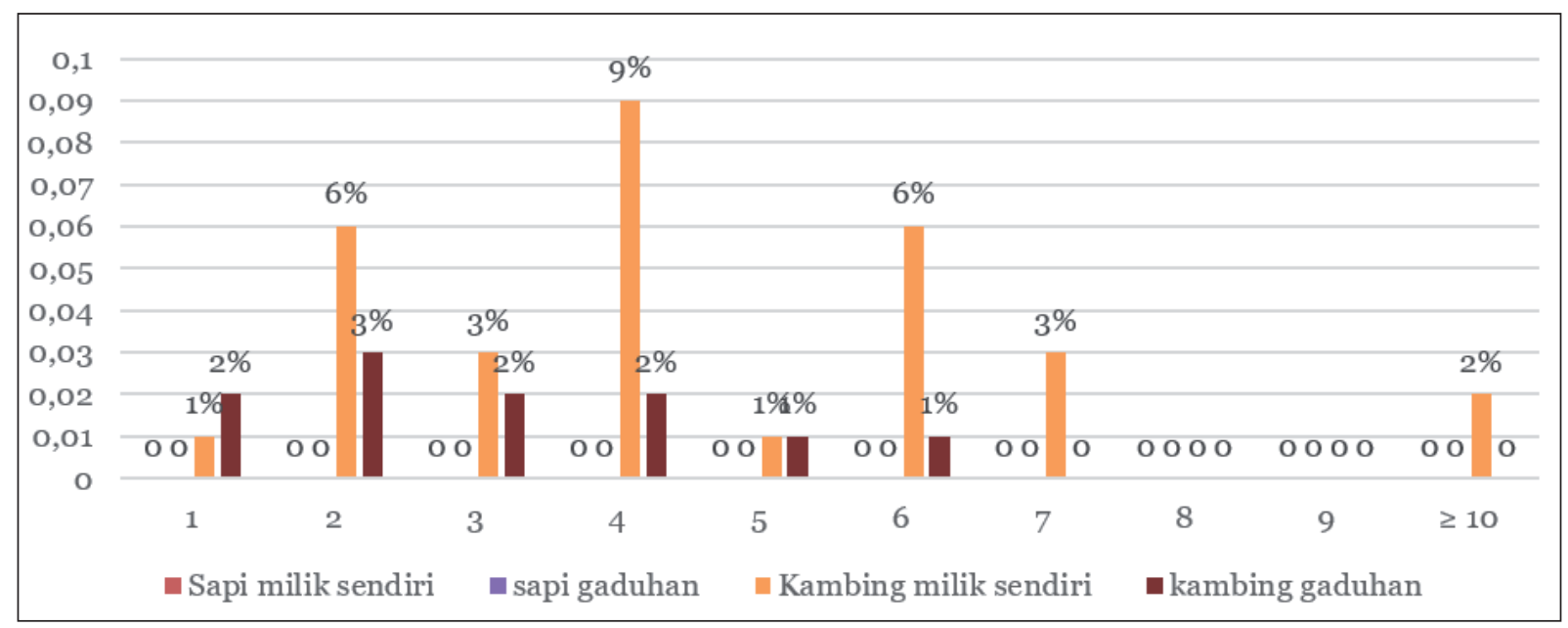

Sumber: Data survei ekonomi rumah tangga, $2020(n=100)$

Gambar 6. Pemeliharaan Ternak di Kalangan Petani Tegal Nduwur

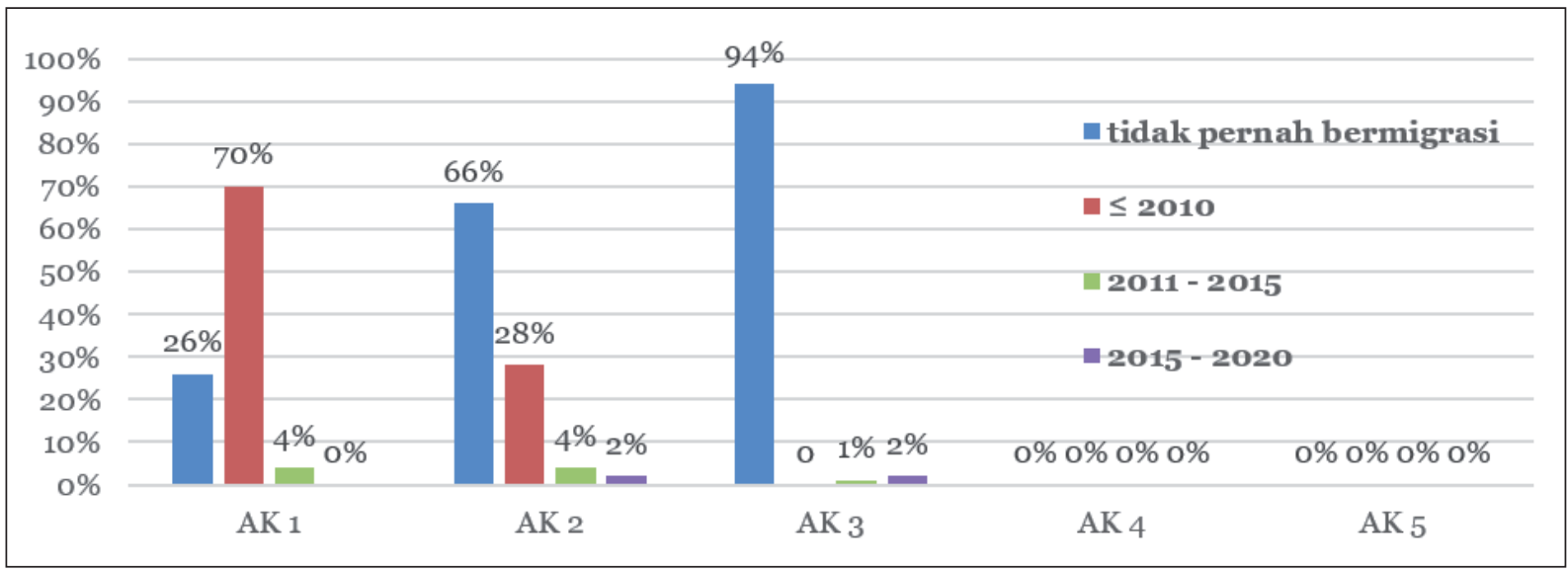

Sumber: Data survei ekonomi rumah tangga $(\mathrm{n}=100 ; \mathrm{AK}=$ anggota keluarga $)$

Gambar 7. Riwayat Migrasi Anggota Rumah Tangga Petani Tegal Nduwur

sekitar 78\% rumah tangga petani memelihara kambing dengan rata-rata enam ekor. Pada Januari 2020, hanya $34 \%$ rumah tangga yang memelihara kambing, pun dengan rata-rata yang lebih rendah. Turunnya pemeliharaan kambing memiliki latar belakang yang serupa sebagaimana pemeliharaan sapi. Namun, kambing masih relatif dapat bertahan karena kebutuhan masukan rumput dan jam kerja yang jauh lebih sedikit daripada sapi. Alasan lain yang melatarbelakangi pemeliharaan kambing adalah, hewan ini dipelihara oleh mereka yang tanah pertaniannya tidak terlalu luas sehingga masih memiliki sedikit tenaga kerja yang bisa dialokasikan untuk merumput. Selain pemeliharaan ternak, pemusatan tenaga kerja ke sektor pertanian telah membuat aliran tenaga kerja ke luar desa melalui migrasi sirkuler turun drastis sebagaimana ditunjukkan dalam Gambar 7.
Data survei rumah tangga 2020 menunjukkan fakta yang sangat kontradiktif dengan anggapan umum mengenai migrasi sirkuler ke kota. Pada 2010, sekitar 56\% penduduk Tegal Nduwur yang berumur minimal 17 tahun pernah dan masih melakukan migrasi sirkuler, baik ke wilayah Pekalongan maupun kota-kota besar lain di Jawa, terutama Jakarta. Pola ini sepertinya cukup mewakili kondisi di tingkat regional. Namun, survei rumah tangga pada tahun 2020 menunjukkan bahwa hanya $4 \%$ dari penduduk Tegal Nduwur yang masih melakukan aktivitas migrasi dalam rentang waktu lima tahun terakhir (2015-2020). Data survei 2020 tersebut menunjukkan bahwa tingkat migrasi sirkuler di Desa Tegal Nduwur turun dengan tajam.

Dalam konteks ini, merosotnya intensitas migrasi sirkuler di kalangan petani Tegal Nduwur 
adalah sesuatu yang harus diterangkan, dan oleh karenanya harus ditempatkan sebagai variabel terikat. Jika migrasi sirkuler dianggap sebagai variabel terikat, variabel bebasnya adalah ketersediaan lapangan kerja yang lebih baik di tingkat desa. Dalam konteks ini, perubahan menuju agroekosistem cepat yang intensif tenaga kerja dan modal tidak hanya menyediakan kesempatan yang lebih baik bagi petani untuk memperoleh pendapatan yang lebih tinggi, tetapi juga lapangan kerja yang lebih besar dan upah yang lebih baik.

Dalam derajat tertentu, kondisi ekonomi rumah tangga yang semakin baik ditunjukkan oleh Gambar 8. Sekitar 47\% rumah tangga yang disurvei memiliki penghasilan di atas 12 juta per tahun atau satu juta per bulan. Namun, besar kemungkinan bahwa agregat penghasilan riil yang mereka peroleh dalam satu tahun jauh lebih besar dari data tersebut. Secara faktual, setiap petak lahan sering kali ditanami berbagai jenis tanaman misalnya kentang dikombinasikan dengan wortel, cabai, atau bawang daun. Dalam survei kali ini, hanya tanaman utama saja yang dicatat. Kedua, meski memiliki tanah sendiri, mereka juga bekerja sebagai buruh tani pada tetangga-tetangga mereka ketika agak longgar. Padahal, upah buruh tani baik untuk perempuan maupun laki laki meningkat dengan tajam. Pada tahun 2008-2009, upah buruh tani perempuan untuk pekerjaan menanam atau menyiangi berkisar antara 6-8 ribu rupiah per hari. Pada 2020, upah buruh tani perempuan naik menjadi 40-50 ribu rupiah per hari. Pada periode yang sama, upah laki-laki juga meningkat dari 10 ribu rupiah menjadi 50-60 ribu rupiah per hari. Dalam ketiadaan pencatatan yang rinci, informasi akurat mengenai penghasilan tambahan inilah yang sulit untuk didapatkan secara detail. Berdasarkan perkiraan ini, besar kemungkinan jika rata-rata penghasilan rumah tangga untuk masing-masing kategori jauh lebih tinggi dibanding apa yang muncul pada Gambar 8 .

Turunnya tingkat migrasi sirkuler juga dipengaruhi oleh perubahan sistem ketenagakerjaan di desa. Pada 2010, sebagian besar petani masih menggunakan sistem tukar menukar tenaga kerja atau sambatan. Pada tanaman subsisten, sistem sambatan memiliki jangkauan luas, sementara untuk tanaman komersial seperti kentang pertukaran tenaga kerja berlangsung antar petani kentang saja. Pada 2020, praktik sambatan menjadi sangat minor dan sebagian besar menggunakan sistem pengupahan. Brahma, pemuda Tegal Nduwur berumur sekitar 16 tahun mengatakan bahwa ketika musim panen, Ia bisa memperoleh setidaknya 250 ribu rupiah per hari. Jumlah tersebut bisa dicapai karena wilayah pertanian di Tegal Nduwur dapat dijangkau dengan motor. Dengan demikian, para pemuda Tegal Nduwur seperti Brahma tidak mengeksploitasi kekuatan tubuh seperti generasi sebelumnya, tetapi memanfaatkan motor untuk mengangkut hasil panen sehingga ora remek awake atau tidak rusak badannya. Oleh karena berbagai sayuran tidak ditanam mengikuti kalender musim yang kaku, peluang kerja tersedia nyaris sepanjang tahun meski dengan kebutuhan tenaga kerja yang berbeda. Selain itu, kerja pertanian saat ini relatif lebih ringan dibanding dahulu sehingga para pemuda Tegal Nduwur seperti Brahma cenderung mengesampingkan pilihan migrasi sirkuler dan memilih bekerja di desa.

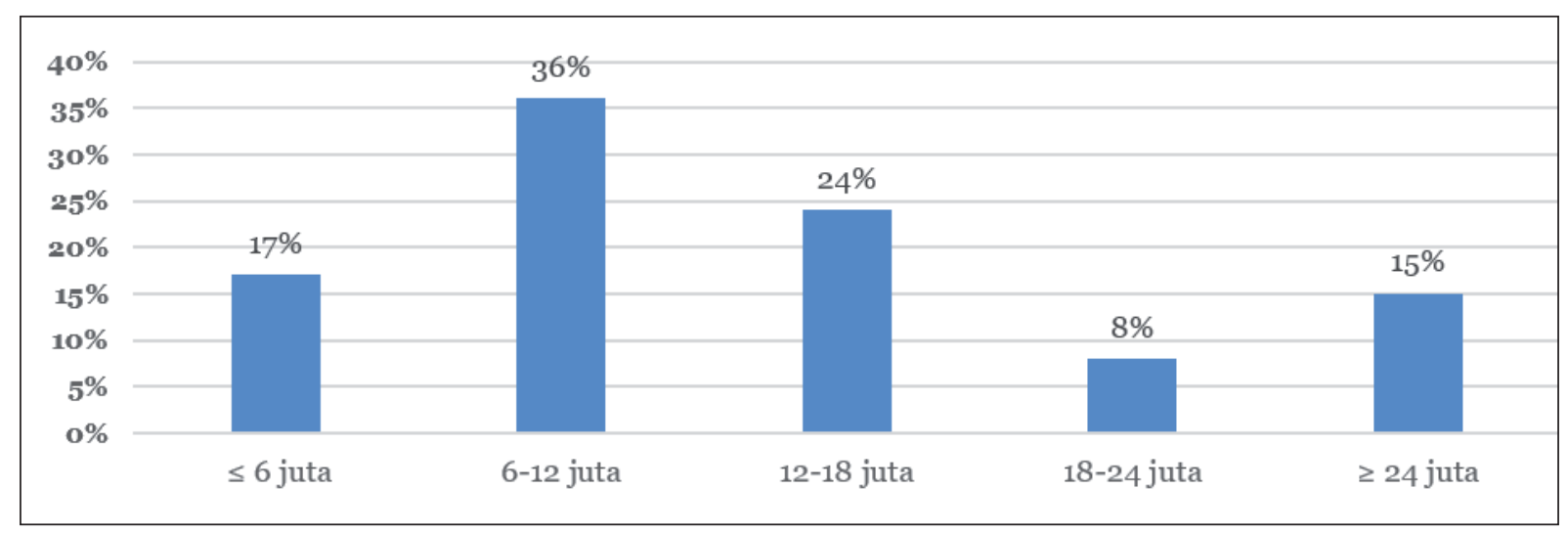

Sumber: Data survei ekonomi rumah tangga $(\mathrm{n}=100 ; \mathrm{AK}=$ anggota keluarga)

Gambar 8. Perkiraan Penghasilan Petani Tegal Nduwur Setahun Terakhir 
Selain persoalan penghasilan, wilayah perkotaan senantiasa menarik karena menyediakan sarana hiburan. Namun saat ini, infrastruktur di kawasan pinggiran juga semakin baik sehingga bahkan di perdesaan, generasi muda dapat seek out and enact a rural modern lifestyle - menemukan dan menjalankan gaya hidup modern perdesaan (White, 2020, 116). Ketika penulis menjalankan riset pada Januari 2020, para pemuda ini sudah memiliki motor, berdandan ala pemuda kota, nongkrong di kafe atau bermain futsal di kota kecamatan, serta bermain game online seiring dengan dipasangnya $\mathrm{Wi}-\mathrm{Fi}$ di kantor desa. Apa yang dahulu hanya mereka temui di perkotaan, saat ini tersedia di sekitar mereka. Melihat data survei dan pengamatan empiris yang muncul dari Desa Tegal Nduwur, agaknya tidak terlalu berlebihan ketika Kang Musta berkata bahwa saat ini, tidak ada lagi orang Tegal Nduwur yang merantau atau bermigrasi secara sirkuler. Di sini, perbaikan infrastruktur dan pasar telah mendorong perubahan agroekosistem sehingga menyediakan lapangan kerja yang cukup besar di desa. Pada titik inilah, migrasi sirkuler mengalami perlambatan yang signifikan.

\section{KESIMPULAN}

Bagi petani Jawa, migrasi sirkuler bukanlah sesuatu yang baru. Sejak industrialisasi di wilayah perkotaan mulai mapan, mereka berangsur-angsur bermigrasi secara sirkuler ke kota, membanjiri sektor konstruksi, jasa informal, atau perdagangan. Bagi rumah tangga petani, migrasi sirkuler merupakan mekanisme untuk mengalirkan sebagian suplus tenaga kerja, sekaligus mendiversifikasi sumber penghasilan selain pertanian dan ternak. Ironisnya, sebagian besar studi hanya membahas sisi positif dan negatif aktivitas ini, tanpa memberikan perhatian serius terhadap dinamika migrasi sirkuler di kalangan petani. Dengan kata lain, migrasi sirkuler dianggap sebagai fenomena yang konstan.

Studi ini menempatkan migrasi sirkuler sebagai variabel terpengaruh sehingga tinggi rendahnya aktivitas migrasi ditentukan oleh beragam faktor. Secara ekonomi, pasca krisis ekonomi 1998, Indonesia mengalami deindustrialisasi sehingga penggerak roda ekonomi justru wilayah pinggiran, terutama melalui sawit dan tanaman komoditas lainnya. Secara politis, desentralisasi juga memungkinkan daerah untuk memiliki kewenangan lebih besar atas pengelolaan sumber daya dan pelaksanaan proyek-proyek pembangunan. Kombinasi antara kedua hal tersebut telah membuat kota menjadi relatif kurang atraktif dibanding dahulu dan pada saat yang bersamaan, menyediakan prakondisi yang baik bagi tumbuhnya ekonomi pinggiran.

Seiring dengan semakin baiknya kondisi pasar, perhatian pemerintah Desa Tegal Nduwur untuk membangun jalan tani menyediakan pondasi yang kokoh bagi transformasi agroekosistem, dari lambat menjadi cepat. Berdasarkan perbandingan data survei antara tahun 2010 dan 2020, pertanian komersial sebagai karakter utama agroekosistem cepat telah diintroduksi oleh hampir semua rumah tangga petani. Dalam perhitungan petani, agroekosistem cepat memberikan lebih banyak peluang untuk menjadi makmur. Namun, introduksi agroekosistem cepat bukanlah sesuatu yang murah sehingga mereka harus mengeluarkan modal dalam jumlah yang lebih besar dan potensi kerugian yang lebih tinggi. Hal ini mendorong mereka untuk mengalirkan sebagian besar tenaga kerja rumah tangga ke sektor pertanian. Upaya pemusatan tenaga kerja ke sektor pertanian salah satunya ditunjukkan oleh merosotnya pemeliharaan ternak. Selain itu, introduksi agroekosistem cepat juga menurunkan intensitas migrasi sirkuler ke perkotaan yang dapat dilihat dari perbandingan data survei 2010 dan 2020. Dengan menyandingkan realitas di tingkat supra desa (makro) dan tingkat desa (mikro), studi ini memberikan indikasi bahwa perlambatan migrasi sirkuler ke perkotaan bukanlah sekedar pencilan atau outlier, tetapi merupakan implikasi atas perubahan sosial ekonomi kawasan perdesaan yang nyata seiring dengan insentif pasar yang semakin besar dan otonomi relatif yang semakin besar.

\section{UCAPAN TERIMA KASIH}

Terima kasih kepada ARC (Australian Research Council) yang telah menyediakan dana untuk penelitian survei. Terimakasih juga kepada FIB UGM yang telah menyediakan dana untuk riset etnografis bagi peneliti utama dan asisten peneliti.

\section{DAFTAR PUSTAKA}

Antlöv, H., Wetterberg, A., \& Dharmawan, L. (2016). Village governance, community life, and the 2014 village law in Indonesia. Bulletin of Indonesian Economic Studies, 52(2), 161-183. 
https://doi.org/10.1080/00074918.2015.11290 47

Booth, A. (2016). Economic change in modern Indonesia: Colonial and post-colonial comparisons. Cambridge University Press. https:// doi.org/10.1017/CBO9781316271438

Constant, A. F., \& Zimmermann, K. F. (2011). Circular and repeat migration: Counts of exits and years away from the host country. Population Research and Policy Review, 30(4), 495-515. https://doi.org/10.1007/s11113-010-9198-6

Gidwani, V., \& Sivaramakrishnan, K. (2003). Circular migration and rural cosmopolitanism in India. Contributions to Indian Sociology, 37(1-2), 339-367. https:/doi. org/10.1177/006996670303700114

Gordon, A. (1982). Indonesia, plantations and the "post-colonial" mode of production. Journal of Contemporary Asia, 12(2), 168-187. https:// doi.org/10.1080/00472338285390141

Hetler, C. B. (1989). The impact of circular migration on a village economy, Bulletin of Indonesian Economic Studies, 25(1), 53-75. https://doi.org /10.1080/00074918812331335509

Hidayat, N. K., Offermans, A., \& Glasbergen, P. (2018). Sustainable palm oil as a public responsibility? On the governance capacity of Indonesian Standard for Sustainable Palm Oil (ISPO). Agriculture and Human Values, 35(1), 223-242. https://doi.org/10.1007/s10460-0179816-6

Hugo, G. (1977). Circular migration. Bulletin of Indonesian Economic Studies, 13(3), 57-66. https:// doi.org/10.1080/00074917712331333184

Hugo, G. (2009). Circular migration and development: An Asia-Pacific perspective. https:// aa.ecn.cz/img upload/6334c0c7298d6b396d21 3ccd19be5999/GHugo_CircularMigrationAndDevelopment.pdf

Jones, G. W. (2002). Southeast Asian urbanization and the growth of mega-urban regions. Journal of Population Research, 19, 119-136. https://doi. org/10.1007/BF03031973

Lewis, W. A. (1954). Economic development with unlimited supplies of labor. Manchester School of Economic and Social Studies, 22(2), 139191. https://doi.org/10.1111/j.1467-9957.1954. tb00021.x

Li, T. M. (2014). Land's end: Capitalist relations on an indigenous frontier. Duke University Press. https://doi.org/10.1215/9780822376460

Makhrova, A.G., Nefedova, T.G., \& Pallot, J. (2016). The specifics and spatial structure of circular migration in Russia. Eurasian Geography and
Economics, 57(6), 802-818. https://doi.org/10 $.1080 / 15387216.2016 .1274663$

McNicoll, G. (1968). Internal migration in Indonesia: Descriptive notes. Indonesia, 5, 29-92. https:// doi.org/10.2307/3350764

Mizuno, K., (2016). The macro-economy, the rural sector, and sustainability. Dalam K. Mizuno \& S.S. Mugniesyah (Ed.), Sustainability and crisis at the village: Agroforestry in West Java Indonesia. UGM PRESS.

Moniruzzaman, M., \& Walton-Roberts, M. (2018). Migration, debt and resource backwash: How sustainable is Bangladesh-Gulf circular migration? Migration and Development, 7(1), 85-103. https://doi.org/10.1080/21632324.20 17.1358799

Nusrat, M. (2003). Politik dagang sapi: Studi tentang perdagangan ternak di kalangan petani Jawa [Skripsi]. Universitas Gadjah Mada.

Petrenko, C., Paltseva, J., \& Searle, S. (2016). Ecological impacts of palm oil expansion in Indonesia. ICCT International Council on Clean Transportation.

Santoso, H. (2015). Bertani itu berjudi: Ketika mekanisme pasar bias spekulasi [Disertasi Doktoral]. Universitas Gadjah Mada.

Semedi, P. (2006). Petungkriyono: Mitos wilayah terisolir. Dalam H. S. Ahimsa-Putra (Ed.), Esei-esei antropologi: Teori, metodologi dan etnografi. Kepel Press.

Semedi, P. (2014). Palm oil wealth and rumour panics in West Kalimantan. Forum for Development Studies, 41(2), 233-252. https://doi.org/10.10 80/08039410.2014.901240

Skeldon, R. (2013). Managing migration for development: Is circular migration the answer? The Whitehead Journal of Diplomacy and International Relations, 11(1), 21-33. https:/www. ciaonet.org/record/29175

Srivastava, R. (2020). Understanding circular migration in India: Its nature and dimensions, the crisis under lockdown and the response of the state. http://www.ihdindia.org/workingpapers/2020/IHD-CES_WP_04_2020.pdf

Syaukani, H. R., Gaffar, A., \& Rasyid, M. R. (2016). Otonomi daerah dalam negara kesatuan. Pustaka Pelajar \& Pusat Pengkajian Etika Politik dan Pemerintahan.

Triandafyllidou, A. (2013). Circular migration at the periphery of Europe: Choice, opportunity, or necessity? Dalam A. Triandafyllidou (Ed.), A circular migration between Europe and its neighbourhood: Choice or necessity? (212-236). Oxford University 
Press. https://doi.org/10.1093/acprof:o so/9780199674510.003.0010

Vertovec, S. (2007). Circular migration: The way forward in global policy? https://www.migrationinstitute.org/publications/wp-04-07

White, B. (1991). Economic diversification and agrarian change in rural Java, 1900-1990. Dalam P. Alexander, P. Boomgaard, \& B. White (Ed.), In the shadow of agriculture: Non-farm activities in the Javanese economy, past and present (41-69). Royal Tropical Institute. https:// doi.org/10.2307/2058014

White, B. (2020). Agriculture and the generation problem. Practical Action Publishing https:// dx.doi.org/10.3362/9781780447421
Wicaksono, A. (2011). Wong cukup lan wong nduwe: Ekualisasi sosial ekonomi pada masyarakat pegunungan Jawa abad ke 20 [Tesis Master]. Universitas Gadjah Mada.

Wickramasekara, P. (2011). Circular migration: a triple win or a dead end? Global Union Research Network, International Labour Office. http://www.migration4development.org/sites/ m4d.emakina-eu.net/files/no15-mar11-circularmigration-a-triple-win-or-a-dead-end.pdf

Zimmermann, K. F. (2014). Circular migration: Why restricting labor mobility can be counterproductive. IZA World of Labor. https:// doi.org/10.15185/izawol.1 